\title{
EKSISTENSI LEMBAGA KERJASAMA BIPARTIT DALAM PERSPEKTIF NEGARA KESEJAHTERAAN DAN HAK ASASI MANUSIA
}

\author{
Ahmad Hunaeni Zulkarnaen \\ Fakultas Hukum Universitas Suryakancana \\ Program Pascasarjana Universitas Suryakancana \\ Email ; ahmadhzul@gmail.com
}

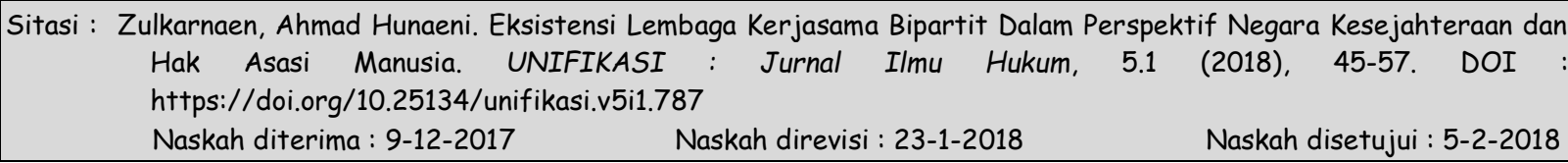

\begin{abstract}
Abstrak : Negara Kesejahteraan Indonesia berdasarkan Pancasila dan Undang-Undang Dasar 1945 bertujuan memajukan kesejahteraan umum yang mengakui, menghormati dan melindungi hak asasi manusia. Tujuan penelitian ini, adalah untuk mengetahui dan menganalisis bagaimana korelasi antara negara kesejahteraan dengan HAM dalam perlindungan tenaga kerja?; dan bagaimana peran Lembaga Kerjasama Bipartit dalam memberikan perlindungan terhadap hak perkerja/buruh? Metode penelitian yang digunakan adalah yuridis normative dengan spesifikasi penelitian deskriptif analitis. Hasil penelitian adalah salah satu sarana dalam hubungan industrial untuk menyampaikan pikiran dengan lisan atau tulisan adalah Lembaga Kerjasama Bipartit, yaitu suatu forum komunikasi, konsultasi dan musyawarah antara wakil pekerja/buruh dan wakil pengusaha dalam suatu perusahaan guna membahas masalah Hubungan Industrial dan kondisi kerja pada umumnya. Kesimpulan, optimaliasi kinerja Lembaga Kerjasama Bipartit dengan tujuan menciptakan hubungan industrial yang harmonis, dinamis, dan berkeadilan demi kelangsungan hidup, pertumbuhan, perkembangan perusahaan, termasuk kesejahteraan pekerja/buruh dan keluarganya sekaligus sebagai sarana untuk mengkoordinasikan lembaga-lembaga ketenagakerjaan.
\end{abstract}

Kata kunci: hak asasi manusia, lembaga kerjasama bipartit, negara kesejahteraan

\section{THE BIPARTITE COOPERATION INSTITUTION OF EXISTENCE IN THE PERSPECTIVE OF THE WELFARE STATE AND HUMAN RIGHTS}

\begin{abstract}
The Indonesian Welfare State based on Pancasila and the 1945 Constitution aims to advance the common welfare that recognizes, respects and protects human rights. The purpose of this study is to know and analyze how the correlation between the welfare state and human rights in labor protection; and how is the role of Bipartite cooperation institution in providing protection to workers / labor rights. The research method used is normative juridical with analytical descriptive specification. The result of the research is as a means in industrial relations to convey thoughts orally or written, this is Bipartite cooperation institution, which is a communication forum, consultation and deliberation between worker/laborer representatives and employer's representative in a company to discuss industrial relations problem and working condition in general. Conclusion, optimizing the performance of Bipartite cooperation institution with the aim of creating harmonious, dynamic, and equitable industrial relations for the sake of survival, growth, development of the company, including the welfare of workers / laborers and also their families as well as a means to coordinate employment agencies.
\end{abstract}

Keywords: human rights, bipartite cooperation institution, welfare state.

\section{PENDAHULUAN}

Indonesia menganut konsep Negara Kemakmuran (Wohlfaart Staats) hal ini juga dapat kita ketahui dari rumusan pada alinea 4 (empat) Pembukaan Undang-Undang Dasar 1945 yang menyatakan, "Kemudian daripada itu untuk membentuk suatu Pemerintah Negara Indonesia yang melindungi segenap bangsa Indonesia dan seluruh tumpah darah Indonesia dan untuk memajukan kesejahteraan umum.......". Tipe Negara Kemakmuran Indonesia adalah "menyelenggarakan kemakmuran rakyat berdasarkan Pancasila dan Undang-Undang Dasar 1945" untuk itu di Indonesia negara diperbolehkan ikut campur dalam kehidupan pribadi warga negaranya, salah satunya ikut campur dalam bidang Ketenagakerjaan termasuk dalam bidang Hubungan Industrial, sehingga khususnya hukum ketenagakerjaan 
UNIFIKASI : Jurnal IImu Hukum, Volume 05 Nomor 01, Januari 2018

semula berdasarkan isinya kaidah hukumnya masuk dalam golongan Kaidah Hukum Privat (sipil) bergesar masuk dalam Kaidah Hukum Publik, yaitu antara lain dengan dikeluarkanya Undang-Undang Nomor 13 Tahun 2003 tentang Ketenagakerjaan, yang mengatur mengenai Hubungan Industrial, yaitu:

"Suatu sistem hubungan di antara pengusaha, pekerja/buruh dan pemerintah yang terjadi di suatu proses produksi untuk menghasilkan barang dan/atau jasa secara produktif,efektif, efisien dan berkelanjutan berdasarkan sila-sila Pancasila dan Undang-Undang Dasar Negara Republik Indonesia Tahun 1945 (Vide Pasal 1 ayat (16) UUK)"

Nilai-nilai Pancasila dan UndangUndang Dasar 1945 merupakan kerangka utama dari suatu sistem hukum hubungan di Indonesia, juga untuk menentukan arah para pelaku proses produksi barang dan jasa demi tercapainya kesejahteraan bagi semua pihak. Karena Pancasila dan Undang-Undang Dasar 1945 merupakan kerangka utama dari suatu sistem hukum hubungan industrial, maka berdasarkan isi kaidahnya hukum hubungan industrial masuk golongan Kaidah Hukum Publik (Vide Pasal 102 s/d 135 UndangUndang Nomor 13 Tahun 2003 tentang Ketenagakerjaan).

Tujuan akhir hubungan industrial adalah peningkatan kesejahteraan semua pihak yaitu pengusaha dan pekerja/buruh. Untuk mencapai hal tersebut diperlukan peningkatan produktivitas dari waktu kewaktu. Produktivitas dapat dicapai manakala pekerja/buruh diakui dan dilindungi hak asasinya dengan memberi peluang kepada pekerja/buruh, yaitu berhak untuk: mengeluarkan pendapatnya, berhak menyatakan keinginannya dan cita-citanya sehingga tercipta ketenangan kerja dan berusaha di dalam suatu perusahaan. Untuk
p-ISSN 2354-5976, e-ISSN 2580-7382

https://journal.uniku.ac.id/index.php/unifikasi

dapat mencapai ketenangan kerja dan berusaha ini, maka komunikasi yang efektif dan berkelanjutan perlu dilakukan secara sadar, karena komunikasi memegang peranan penting didalam membina dan meningkatkan saling percaya, ${ }^{2}$ untuk itu diperlukan Lembaga Kerjasama Bipartit yang merupakan salah satu sarana hubungan industrial yang berfungsi sebagai forum komunikasi dan konsultasi mengenai hal-hal yang berkaitan dengan hubungan industrial di satu perusahaan yang anggotanya terdiri dari pengusaha dan serikat pekerja/serikat buruh yang sudah tercatat di instansi yang bertanggung jawab di bidang ketenagakerjaan atau unsur pekerja/buruh (Vide Pasal 1 ayat (18) UU No 13 Tahun 2003 tentang Ketenagakerjaan).

\section{RUMUSAN MASALAH}

Berdasarkan latar belakang yang telah dipaparkan diatas, maka rumusan masalah dalam penelitian ini, adalah: 1) Bagaimana korelasi antara negara kesejahteraan dengan HAM dalam perlindungan tenaga kerja?; 2) Bagaimana peran Lembaga Kerjasama Bipartit dalam memberikan perlindungan terhadap hak perkerja/buruh?

\section{METODE PENELITIAN}

Metode yang digunakan dalam penelitian ini adalah yuridis normative yaitu pengumpulan data melalui studi kepustakaan berupa bahan hokum primer mulai dari Unadng Undang Dasar Negara Republik Indonesia 1945 dan bahan hukum sekunder yaitu sumber-sumber yang berkaitan dengan penelitian ini yaitu buku, jurnal, teori-teori dari para ahli, sedangkan spesifikasi

Suwarto,2003, Hubungan Industrial Dalam Praktek, Asosiasi Hubungan Industrial Indonesia, Jakarta, hlm 14. 
UNIFIKASI : Jurnal IImu Hukum, Volume 05 Nomor 01, Januari 2018

penelitian ini adalah deskriptif analitis yaitu dengan cara mengumpulkan bahan yang sesuai dengan pengkajian ini kemudian dipelajari dan dituangkan dalam bentuk narasi serta dianalisis.

\section{PEMBAHASAN}

\section{Negara Hukum Demokrasi Indonesia Berdasarkan Pancasila dan Undang-Undang Dasar 1945}

Negara dan/atau pemerintahan (Indonesia: penulis) yang menganut paham demokrasi, yang memberi peluang kepada rakyat berhak untuk: mengeluarkan pendapatnya, berhak menyatakan keinginannya dan cita-citanya tentang kenegaraan selaras dengan dasar negara yang bersangkutan ${ }^{3}$ tegasnya Indonesia menganut teori kedaulatan rakyat, selain itu juga Indonesia menganut teori kedaulatan hukum, atau jelasnya Indonesia adalah negara hukum yang demokratis, yaitu negara yang berdasarkan hukum dengan kedaulatan berada di tangan rakyat Indonesia (Vide pasal 1 ayat (2) dan ayat (3) Undang-Undang Dasar 1945), pengertian demokrasi berasal dari kata Yunani demos (rakyat) dan kratos (pemerintahan), pengertian demokrasi berarti pemerintahan rakyat, yaitu pemerintahan yang rakyatnya sangat memegang peranan yang sangat menentukan, dalam segala urusan yang dilakukan oleh negara dalam menyelenggarakan kesejahteraan masyarakat dan kepentingan negara. Peranan hukum di dalam pergaulan hidup adalah sebagai sesuatu yang melindungi, memberi rasa aman, tentram dan tertib

3 C.S.T. Kansil dan Christine S.T. Kansil, 2007, Hukum Tata Negara Di Indonesia, Sinar Grafika, Jakarta, hlm 90.
p-ISSN 2354-5976, e-ISSN 2580-7382

https://journal.uniku.ac.id/index.php/unifikasi

untuk mencapai kedamaian dan keadilan setiap orang. ${ }^{4}$

Konsep negara hukum yang

demokrasi, memberikan hak kepada rakyat untuk mengeluarkan pendapatnya, menyatakan keinginannya dan cita-citanya tentang kenegaraan selaras dengan dasar negara yang bersangkutan, untuk negara Indonesia keinginan dan cita-cita rakyat tentang kenegaraan diwakilkan kepada partaipartai politik yang ada (PDI-P, Golkar, PKS, PPP dsb). Negara demokrasi, menganut teori kedaulatan rakyat, yaitu tujuan negara adalah untuk menegakan hukum dan menjamin kebebasan para warga negaranya, dalam pengertian bahwa kebebasan disini adalah kebebasan dalam batas-batas perundangundangan, sedangkan undang-undang disini yang berhak membuatnya adalah rakyat itu sendiri, undang-undang adalah merupakan penjelmaan daripada kemauan atau kehendak rakyat. Jadi rakyatlah yang mewakili kekuasaan tertinggi atau berdaulat dalam negara. $^{5}$ dalam negara demokrasi berlaku konfigurasi politik yang demokratis yang akan melahirkan hukum yang responsif, dengan karakter pembuatan hukumnya bersifat partisipatif (tidak sentralistik-dominatif), muatannya aspiratif (muatannya tidak positivist-instrumentalistik) dan rincian isinya limitatif (rincian isinya tidak open interpretative). ${ }^{6}$

Indonesia menganut faham negara demokrasi dimana Kedaulatan berada di

\footnotetext{
${ }^{4}$ Gios Adyaksa, Penerapan Asas Perlindungan Yang Seimbang Menurut Kuhperdata Dalam Pelaksanaan Perjanjian Kerja Untuk Waktu Tertentu Dihubungkan Dengan Undang-Undang Nomor 13 Tahun 2003 Tentang Ketenagakerjaan, Jurnal Unifikasi, ISSN 2354-5976 Vol. 3 No. 2 Juli 2016, FH-UNIKU, hlm. 78.

${ }^{5}$ Soehino, dalam Abu Daud Busroh, 1990, Ilmu Negara, Bumi Aksara, Jakarta, hlm 72.

${ }^{6}$ Moh. Mahfud MD, 2009, Politik Hukum di Indonesia, Cetakan I, II dan III, PT RajaGrafindo Persada, Jakarta, hlm 7 .
} 
UNIFIKASI : Jurnal IImu Hukum, Volume 05 Nomor 01, Januari 2018

tangan rakyat dan dilaksanakan menurut Undang-Undang Dasar (Vide pasal 1 ayat (2) Undang-Undang Dasar 1945), Indonesia sebagai negara demokrasi yang berdasarkan Pancasila, ialah " Kerakyatan yang dipimpin oleh hikmah kebijaksanaan dalam permusyawaratan perwakilan" yang merupakan sila keempat dari Dasar Negara Pancasila sebagaimana tercantum dalam alinea ke 4 (empat) Pembukaan UndangUndang Dasar Tahun 1945. Penerapan Demokrasi Pancasila harus dijiwai oleh SilaSila: Ketuhanan Yang Maha Esa, Kemanusiaan yang adil dan beradab, Persatuan Indonesia dan Keadilan Sosial bagi seluruh rakyat Indonesia. ${ }^{7}$ Dengan demikian hakikat Demokrasi Pancasila, ialah Kerakyatan atau Demokrasi yang:

1. Berlandaskan Ketuhanan Yang Maha Esa (religius);

2. Berkemanusiaan yang adil dan beradab (humanistis);

3. Mempertahankan persatuan Indonesia (nasionalistis);

4. Menuju kepada/mencapai keadilan sosial bagi seluruh rakyat Indonesia (sosialisme Indonesia). Sosialisme Indonesia, ialah sosialisme yang religius, humanistis, nasionalistis, dan demokratis. Hal ini sesuai dengan totalitas dari Pancasila, yaitu tiap-tiap Sila dari Pancasila menjiwai dan dijiwai oleh sila-sila lainnya dari Pancasila. ${ }^{9}$ Secara ideologi dan secara konstitusional, asas demokrasi Pancasila mencerminkan wajah demokrasi Indonesia yang bersumberkan tata nilai sosial budaya bangsa. Identitas demokrasi Pancasila adalah sila keempat, yang dijiwai dan

7 C.S.T. Kansil dan Christine S.T. Kansil, Op. Cit, hlm 176

${ }^{1}$ Ibid, hlm 176-177.

$9 \quad$ Ibid, , hlm 177
p-ISSN 2354-5976, e-ISSN 2580-7382

https://journal.uniku.ac.id/index.php/unifikasi

diliputi oleh sila kesatu, kedua, ketiga, dan menjiwai serta meliputi sila kelima, asas ini mengajarkan prinsip-prinsip: persamaan, keseimbangan antara hak dan kewajiban, kebebasan yang bertanggung jawab, musyawarah mufakat, keadilan sosial, persatuan nasional dan keluarga dan cita-cita nasional. ${ }^{10}$ prinsip-prinsip tersebut sebagai kebenaran yang dipergunakan sebagai tumpuan berpikir dan alasan pendapat dalam menjalankan negara demokrasi Pancasila.

Sumber hukum demokrasi Pancasila adalah Pembukaan dan Batang tubuh UndangUndang Dasar 1945, dalam Pembukaan Undang-Undang Dasar menyatakan "...maka disusunlah kemerdekaan kebangsaan Indonesia dalam suatu Undang-Undang Dasar Negara Republik Indonesia yang berbentuk dalam suatu susunan negara Republik Indonesia yang berkedaulatan rakyat..." selanjutnya dalam batang tubuh UndangUndang Dasar 1945, khususnya dalam Pasal 1 ayat (2)nya, menyatakan "Kedaulatan berada di tangan rakyat dan dilaksanakan menurut Undang-Undang Dasar", dalam hal Undang-Undang Dasar 1945.

Selain sebagai Negara Demokrasi Pancasila, Indonesia merupakan Negara Hukum (Vide pasal 1 ayat (3) Undang-Undang Dasar 1945, amandemen ke 3), sedangkan dalam penjelasan Undang-Undang Dasar 1945 Sistem Pemerintahan Negara (sebelum amandemen) disebutkan bahwa "Negara Indonesia berdasarkan atas hukum (rechstaat), tidak berdasarkan atas kekuasaan belaka (machstaat)". Hal ini mengandung makna bahwa, Pertama, sistem pemerintahan berdasarkan atas sistem konstitusi (hukum dasar), tidak bersifat absolutisme (kekuasaan yang tidak

10 Ibid, hlm 171. 
UNIFIKASI : Jurnal IImu Hukum, Volume 05 Nomor 01, Januari 2018

terbatas), kedua, kedaulatan ada ditangan rakyat dan dilaksanakan menurut UndangUndang Dasar. ${ }^{11}$ dimana hukumlah yang berdaulat dan negara dipandang sebagai subjek hukum, apabila negara salah, maka negara dapat dituntut di muka pengadilan sebagaimana halnya dengan subjek hukum lainnya. $^{12}$

Teori atau pola negara hukum Indonesia telah disesuaikan dengan kondisi Indonesia, yaitu menggunakan pandangan hidup bangsa Indonesia, Pancasila. hal ini sesuai dengan pandangan Azhary yang menyatakan bahwa. "Kalau konsep negara hukum Eropa kontinental dan konsep negara hukum Anglo Saxon didasarkan kepada paham liberal individualistis, maka konsep negara hukum Indonesia didasarkan kepada pandangan hidup bangsa Indonesia Pancasila" 13. demikian juga dengan Sri Sumantri merumuskan negara hukum Pancasila : Setiap pemegang kekuasaan dalam menjalankan tugas dan wewenangnya harus mendasarkan diri atas norma-norma hukum yang berlaku, baik yang tertulis maupun yang tidak tertulis, dan norma-norma hukum itu harus berdasarkan Pancasila". ${ }^{14}$

Konsep negara Indonesia, adalah Negara Hukum Demokratis yang berdasarkan Pancasila hal ini dapat kita ketahui pada rumusan alinea 4 (empat) Pembukaan UndangUndang Dasar 1945 yang menyatakan " Kemudian daripada itu.................yang terbentuk dalam suatu susunan Negara Republik Indonesia yang berkedaulatan

11 KIF. Aminanto, 2017, Politik Hukum Pidana, Disparitas Putusan Hakim dalam Tindak Pidana Korupsi, Cetakan ke I, Jember Katamedia, Jember,.hlm 68.

12 C.S.T. Kansil dan Christine S.T. Kansil, Hukum..., Op. Cit, hlm 126.

13 Azhary, 1995, Negara Hukum Indoensia, Analisis Yuridis Normatif Tentang Unsur-Unsurnya, UI Press, Jakarta, hlm 143.

14 Ibid, hlm 143.
p-ISSN 2354-5976, e-ISSN 2580-7382

https://journal.uniku.ac.id/index.php/unifikasi

rakyat dengan berdasar kepada Ketuhanan Yang Maha Esa, Kemanusiaan yang adil dan beradab, Persatuan Indonesia dan Kerakyatan yang dipimpin oleh hikmat kebijaksanaan dalam Permusyawaratan/Perwakilan, serta dengan mewujudkan suatu $\mathrm{Ke}$ - adilan sosial bagi seluruh rakyat Indonesia".

\section{Negara Kesejahteraan Indonesia dan Hak-Hak Asasi Manusia}

Selain menganut konsep Negara Hukum Demokratis yang berdasarkan Pancasila dan Undang-Undang Dasar 1945, Indonesia juga menganut konsep Negara Kemakmuran (Wohlfaart Staats) hal ini juga dapat kita ketahui dari rumusan pada alinea 4 (empat) Pembukaan Undang-Undang Dasar 1945 yang menyatakan, "Kemudian daripada itu untuk membentuk suatu Pemerintah Negara Indonesia yang melindungi segenap bangsa Indonesia dan seluruh tumpah darah Indonesia dan untuk memajukan kesejahteraan umum......." menurut Padmo Wahjono:

"Pada tipe Negara Kemakmuran negara mengabdi sepenuhnya kepada masyarakat, negara alat satu-satunya untuk menyelenggarakan kemakmuran rakyat, negara aktif dalam menyelenggarakan kemakmuran warganya, untuk kepentingan seluruh negara, tugas negara sematamata semaksimal mungkin menyelengarakan kemakmuran rakyat" ${ }^{\prime 15}$

Bangsa dan negara Indonesia menganut pandangan hidup berdasarkan Pancasila dan Undang-Undang Dasar 1945, maka tujuan pada tipe Negara Kemakmuran Indonesia adalah "menyelenggarakan kemakmuran rakyat berdasarkan Pancasila dan Undang-Undang Dasar 1945" untuk itu

15 Abu Daud Busroh, 1990, Ilmu Negara, Bumi Aksara, Jakarta, hlm 54-55. 
UNIFIKASI : Jurnal IImu Hukum, Volume 05 Nomor 01, Januari 2018

maka negara Indonesia diperbolehkan ikut campur dalam kehidupan pribadi warga negaranya, salah satunya, adalah negara Indonesia ikut campur dalam bidang Ketenagakerjaan termasuk dalam bidang Hubungan Industrial, sehingga hukum ketenagakerjaan semula berdasarkan isinya kaidah hukumnya masuk dalam golongan Kaidah Hukum Privat (sipil) bergesar masuk dalam Kaidah Hukum Publik, antara lain dengan adanya Undang-Undang Nomor 13 Tahun 2003 tentang Ketenagakerjaan yang dalam Pasal 1 ayat (16) mengatur mengenai Hubungan Industrial, yaitu:

" Suatu sistem hubungan yang terbentuk antara para pelaku dalam proses produksi barang dan/atau jasa yang terdiri dari unsur pengusaha, pekerja/buruh, dan pemerintah yang didasarkan pada nilai-nilai Pancasila dan Undang-Undang Dasar Negara Republik Indonesia Tahun 1945.

Nilai-nilai Pancasila dan UndangUndang Dasar 1945 merupakan kerangka utama dari suatu sistem hukum hubungan industrial dan menentukan arah bagi para pelaku dalam proses produksi barang dan jasa untuk mencapai kesejahteraan bagi semua pihak. Karena Pancasila dan Undang-Undang Dasar 1945 merupakan kerangka utama dari suatu sistem hukum hubungan industrial, maka berdasarkan isi kaidahnya hukum hubungan industrial masuk golongan Kaidah Hukum Publik (Vide Pasal 102 s/d 135 Undang-Undang Nomor 13 Tahun 2003 tentang Ketenagakerjaan). Hukum publik adalah kaidah-kaidah hukum yang mengatur hal-hal ketatanegaraan, antara lain menyangkut cara-cara perwujudan hubungan hukum antara pemerintah (negara) dengan masyarakat. Hukum privat mengatur tata tertib masyarakat yang menyangkut kepentingan individu/perorangan para warga
p-ISSN 2354-5976, e-ISSN 2580-7382

https://journal.uniku.ac.id/index.php/unifikasi

masyarakat, khususnya antara lain dalam urusan-urusan hubungan antar individu/perorangan di dalam masyarakat. ${ }^{16}$

Walaupun negara diperkenankan untuk ikut campur dalam urusan pribadi warga negaranya sesuai identitas Indonesia sebagai Negara Hukum (Vide Pasal 1 ayat (3) Undang-Undang Dasar 1945 amandemen 3), ikut campur negara tersebut harus berdasarkan hukum dan harus menghormati serta melindungi hak asasi manusia, karena negara hukum Indonesia yang berdasarkan Pancasila, adalah negara yang menghormati dan melindungi hak-hak manusia untuk itu, Padmo Wahjono mengungkapkan bahwa dalam negara Hukum Pancasila terdapat suatu pola "menghormati dan melindungi hak-hak manusia, mekanisme kelembagaan negara yang demokratis, tertib hukum, kekuasaan kehakiman yang bebas" ${ }^{17}$. salah satu ciri dari pola negara hukum Pancasila adalah "menghormati dan melindungi hak-hak manusia atau hak asasi manusia", yaitu "hak dasar atau hak pokok yang dibawa sejak lahir sebagai anugrah dari Tuhan Yang Maha Esa"18 atau:

" Seperangkat hak yang melekat pada hakikatnya dan keberadaan manusia sebagai makhluk Tuhan Yang Maha Esa dan merupakan anugerahNya yang wajib di hormati, dijunjung tinggi dan dilindungi oleh negara, hukum, Pemerintah, dan setiap orang demi kehormatan serta perlindungan harkat dan

16 Tim Pengajar PIH Fakultas Hukum Unpar, 1995, Pengantar PIH, Universitas Katolik Parahyangan Fakultas Hukum, Bandung, $\mathrm{h} / \mathrm{m}$ 69-70.

17 Padmo Wahjono, 1983, Indonesia Berdasarkan Atas Hukum, Ghalia Indonesia, Jakarta , hlm9-10.

18 C.S.T. Kansil dan Christine S.T. Kansil, Hukum ..., Op. Cit, hlm 201. 
UNIFIKASI : Jurnal IImu Hukum, Volume 05 Nomor 01, Januari 2018

martabat manusia (Vide Pasal 1 ayat (1) Undang-Undang Nomor 39 Tahun 1999 tentang Hak Asasi Manusia)".

\section{Hak Menyampaikan Pikiran dengan Lisan Atau Tulisan dan Lembaga Kerjasama Bipartit}

Berlangsungnya hak dan kebebasan tiap-tiap orang, merupakan salah jenis dari hak asasi manusia, untuk itu Immanuel Kant (1724-1804) mengatakan bahwa kewajiban negara menjamin kedudukan hukum yang teratur dari segenap warga negara, adapun yang menjadi tujuan negara ialah membentuk dan menjamin berlangsungnya hak dan kebebasan tiap-tiap orang. ${ }^{19}$ dan salah satu dari hak dan kebebasan tiap-tiap manusia, adalah hak dan kebebasan atau kemerdekaan tiap-tiap manusia atau warga negara untuk menyampaikan pendapat yaitu:

" hak setiap warga negara untuk menyampaikan pikiran dengan lisan. tulisan. dan sebagainya secara bebas dan bertanggung jawab sesuai dengan ketentuan peraturan perundang-undangan yang berlaku (Vide Pasal 1 ayat (1) UndangUndang 9 Tahun 1998 tentang Kemerdekaan Menyampaikan Pendapat dimuka Umum)"

Pancasila dan Undang-Undang Dasar 1945 merupakan kerangka utama dari politik hukum nasional, tersebar dalam berbagai norma yang telah dicanangkan oleh pemerintah ${ }^{20}$ antara lain untuk menentukan arah para pihak dalam Lembaga Kerja Sama Bipartit atau lembaga-lembaga

Ibid, hlm 201.

20 KIF. Aminanto, 2017, Politik Hukum Pidana, Disparitas Putusan Hakim dalam Tindak Pidana Korupsi, Cetakan ke I, Jember Katamedia, Jember," hlm 69.
p-ISSN 2354-5976, e-ISSN 2580-7382

https://journal.uniku.ac.id/index.php/unifikasi

ketenagakerjaan lainnya dalam perusahaan (GKM, P2K3, Koperasi Karyawan dan lain-lain) untuk menyampaikan pikiran baik lisan maupun tulisan dan sebagainya secara bebas, bertanggung jawab sesuai dengan ketentuan peraturan perundang-undangan dalam suatu forum komunikasi Lembaga Kerja Sama Bipartit yaitu lembaga hubungan industrial yang berfungsi sebagai suatu forum komunikasi, konsultasi dan musyawarah antara wakil pekerja/buruh dan wakil pengusaha dalam suatu perusahaan guna membahas masalah Hubungan Industrial dan kondisi kerja pada umumnya. ${ }^{21}$ atau:

"Forum komunikasi dan konsultasi mengenai hal-hal yang berkaitan dengan hubungan industrial di satu perusahaan yang anggotanya terdiri dari pengusaha dan serikatpekerja/serikat buruh yang sudah tercatat di instansi yang bertanggung jawab di bidang ketenagakerjaan atau unsur pekerja/buruh (Vide Pasal 1 ayat (18) UU No 13 Tahun 2003 tentang Ketenagakerjaan)"

Tujuan Lembaga Kerja Sama Bipartit, adalah menciptakan hubungan industrial yang harmonis, dinamis, dan berkeadilan dalam suatu perusahaan dengan fungsi sebagai forum komunikasi dan konsultasi antara pengusaha dengan wakil serikat pekerja/serikat buruh dan/atau wakil pekerja/buruh dalam rangka pengembangan hubungan industrial untuk kelangsungan hidup, pertumbuhan, dan perkembangan perusahaan, termasuk kesejahteraan pekerja/buruh. Dengan tugas, melakukan pertemuan secara periodik

\footnotetext{
21 Kementerian Tenaga Kerja dan Transmigrasi Republik Indonesia, Sekretariat Jendral Pusat Pendidikan dan Pelatihan Pegawai,2013, Modul Lembaga Bipartit, Jakarta, $\mathrm{hlm}$ i.
} 
UNIFIKASI : Jurnal IImu Hukum, Volume 05 Nomor 01, Januari 2018

dan/atau sewaktu-waktu apabila diperlukan, mengkomunikasikan kebijakan pengusaha dan aspirasi pekerja/buruh dalam rangka mencegah terjadinya permasalahan hubungan industrial di perusahaan, menyampaikan saran pertimbangan dan pendapat kepada pengusaha, pekerja/buruh, serikat pekerja/serikat buruh dalam rangka penetetapan dan kebijakan perusahaan ${ }^{22}$ baik penetetapan dan kebijakan perusahaan yang berkaitan dengan pembentukan, pelaksanaan, pengembangan lembaga-lembaga ketenagakerjanaan (GKM, TQM, ISO, P2K3, Koperasi Karyawan dan lain-lain), maupun jenis-jenis kebijakan perusahaan lainnya, seperti:

1. Hari kerja dan jam kerja seperti: Jam kerja, jam kerja lembur, cara pembayaran upah lembur, tambahan uang disamping uang lembur untuk pekerja/buruh yang bekerja lembur pada Hari Besar Resmi Nasional (Idul Fitri, Idul Adha dII);

2. Premi produksi atau bonus produksi;

3. Cara penggajian, seperti: sistem penggajian perminggu, perdua minggu, perbulan;

4. Hubungan kerja, seperti: Pengangkatan pekerja tetap dan tidak tetap, jenis-jenis pekerjaan;

5. Pembebasan bagi pekerja/buruh dari kewajiban untuk bekerja, seperti: Istirahat mingguan, cuti hamil, cuti keguguran kandungan, cuti tahunan, cuti haid, cuti panjang, cuti haji atau umroh, ijin meninggalkan pekerjaan untuk pekerja/buruh yang dapat diberikan oleh perusahaan;

6. Fasilitas dana pengobatan dan jaminan sosial, seperti: Tunjangan pakaian kerja, tunjangan BPJS Ketenagakerjaan, tunjangan sakit, tunjangan sementara

22 Ibid, hlm 5-6.
p-ISSN 2354-5976, e-ISSN 2580-7382

https://journal.uniku.ac.id/index.php/unifikasi

tidak mampu bekerja, tunjangan kecelakaan kerja, tunjangan meninggal dunia, tunjangan Hari Raya Idul Fitri (THR), tunjangan pernikahan/melahirkan/khitanan, koperasi pekerja/buruh, keluarga berencana, rekreasi;

7. Tata tertib kerja, seperti: Tata tertib registrasi, tata tertib keselamatan kerja, tata tertib kesehatan dan kebersihan, tata tertib keamanan, tata tertib absensi kerja, tata tertib umum;

8. Pemutusan hubungan kerja dan sanksisanksi terhadap pelanggaran disiplin, seperti:Disiplin kerja, jenis-jenis pelanggaran dengan sanksi surat peringatan pertama dan/atau kedua, surat peringatan terakhir, pemutusan hubungan kerja, efesiensi, batas usia pensiun pekerja/buruh, uang pesangon, uang penghargaan masa kerja, uang penggantian hak, pekerja/buruh mengundurkan diri, ganti rugi:dan

9. Tanggapan terhadap keluh kesah pekerja/buruh dan cara penyelesaiannya.

Susunan keanggotaan Lembaga Kerja Sama Bipartit terdiri dari unsur pengusaha dan unsur pekerja/buruh yang ditunjuk oleh pekerja/buruh secara demokratis untuk mewakili kepentingan pekerja/buruh di perusahaan yang bersangkutan (Vide Pasal 106 ayat (2) dan ayat (3) Undang-Undang Nomor 13 Tahun 2003 tentang Ketenagakerjaan).

\section{Prosedur Komunikasi dan Musyawarah dalam Lembaga Kerjasama Bipartit \\ Lembaga Kerja Sama Bipartit, merupakan salah satu pelaksanaan prinsip demokrasi Pancasila dalam bidang ketenagakerjaan atau dalam bidang hubungan industrial. Oleh karenanya prosedur pelaksanaan komunikasi, konsultasi dalam}


UNIFIKASI : Jurnal IImu Hukum, Volume 05 Nomor 01, Januari 2018

Lembaga Kerja Sama Bipartit dapat mengacu kepada Pasal 87 Ketetapan MPR No. I/MPR/1983 tentang Peraturan Tata Tertib Majelis Permusyawaratan Rakyat yang juga dapat diterapkan dalam lembaga-lembaga kemasyarakatan di Indonesia ${ }^{23}$ atau lembagalembaga ketenagakerjaan dalam perusahaan seperti Lembaga Kerja Sama Bipartit (LKSB), Gugus Kendali Mutu (GKM), Koperasi Pekerja, Panitia Pembina Kesehatan dan Keselamatan Kerja (P2K3), Total Quality Mutu (TQM), Iternational Organization For Standarzation (ISO), adapun prosedur pelaksanaan komunikasi dalam lembaga kerjasama bipartite, adalah:

1. Pengambilan putusan pada asasnya diusahakan sejauh mungkin dengan musyawarah untuk mencapai mufakat dan sedapat mungkin dihindari putusan diambil berdasarkan suara terbanyak;

2. Mufakat sebagai hasil musyawarah, haruslah bermutu tinggi yang dapat dipertanggungjawabkan dan tidak bertentangan dengan tujuan akhir hubungan industrial Pancasila, yaitu " Keuntungan Perusahaan Berkorelasi dengan Kesejahteraan Pekerja/Buruh dan keluarganya dan visi, misi, tujuan lembagalembaga ketenagakerjaan yang ada di perusahaan tersebut (LKSB, GKM, TQM, ISO, P2K3, Koperasi Pekerja/Buruh dan lain-lain).

3. Musyawarah menuju ke arah persatuan dengan mengutamakan ikut sertanya semua pihak yang terlibat dalam hubungan industrial serta berpangkal tolak pada sikap harga menghargai setiap pendirian, keinginan semua pihak yang terlibat dalam hubungan industrial (perusahaan, pekerja/buruh, pemerintah) atau antar

${ }^{23}$ C.S.T. Kansil dan Christine S.T. Kansil, Hukum..., Op.Cit, hlm 177.
p-ISSN 2354-5976, e-ISSN 2580-7382

https://journal.uniku.ac.id/index.php/unifikasi

lembaga-lembaga ketenagakerjaan yang ada di perusahaan tersebut (LKSB, GKM, TQM, ISO, P2K3, Koperasi Pekerja/Buruh dan lain-lain);

4. Semua pihak bermusyawarah mempunyai hak dan kesempatan yang sama bebasnya untuk mengemukakan pendapat dan melahirkan kritik yang bersifat membangun tanpa tekanan dari pihak manapun, terutama bebas dari tekanan perusahaan;

5. Semua pihak diberikan kesempatan sama untuk mengemukakan pendapat serta saran sebagai sumbangan pendapat dan pikiran bagi penyelesaian masalah yang sedang dimusyawarahkan, terutama pihak perusahaan mengusahakan secara bijaksana agar musyawarah segera dapat mencapai mufakat;

6. Dibuat notulen kesimpulan hasil musyawarah atau kesefakatan yang mencerminkan pendapat- pendapat semua pihak yang hidup dalam musyawarah.

Hal-hal yang dibahas atau dimusyawarahkan dalam pertemuan Lembaga Kerja Bipartit antara lain adalah:

1. Mencegah Terjadinya Permasalahan Hubungan Industrial, yaitu menghindari sedini mungkin akan timbulnya kesalah pahaman atau perbedaan pendapat dalam permusyawaratan yang menyangkut kepentingan bersama sehingga tidak terjadi permasalahan ketenagakerjaan ${ }^{24}$.

2. Kelangsungan hidup, pertumbuhan, dan perkembangan perusahaan termasuk kesejahteraan pekerja/buruh, yaitu:

a. Berupaya memelihara dan meningkatkan kondisi yang baik di tempat kerja dalam rangka menuju ketenangan bekerja dan

24 Kementerian Tenaga Kerja dan Transmigrasi, Op. Cit, hlm 6. 
UNIFIKASI : Jurnal IImu Hukum, Volume 05 Nomor 01, Januari 2018

ketenteraman berusaha maupun kelangsungan hidup perusahaan;

b. Menciptakan iklim kondusif di tempat kerja yang mengarah kepada suatu keadaan yang lebih baik dari sebelumnya;

c. Kegiatan-kegiatan yang mengarah pada peningkatan disiplin kerja maupun motivasi kerja dari para pekerja maupun pengusaha perlu diupayakan agar masing-masing dapat menjalin hubungan dengan baik dan professional;

d. Peningkatan disiplin kerja maupun motivasi kerja dapat dilakukan dengan menanamkan pengertian dan melaksanakan Hubungan Industrial serta melaksanakan perbaikan, perubahan sistem kerja secara terus menerus dengan menggunakan teknik gugus kendali mutu ${ }^{25}$.

3. Pembinaan Sumber Daya Manusia (SDM), yaitu mendorong peningkatan kualitas SDM yang mengacu kepada standar kompetensi (skill, know/edge dan attitude) yang dapat dilakukan dengan mengadakan latihan-Iatihan, kursuskursus sesuai dengan keterampilan yang dibutuhkan perusahaan.

Peningkatan keterampilan membawa dampak yang positif kepada perusahaan maupun peningkatan kesejahteraan pekerja dapat dijelaskan sebagai berikut :

a. Dengan meningkatkan keterampilan para pekerja/buruh akan dapat meningkatkan produksi maupun kualitas sehingga perusahaan dapat bersaing dengan perusahaan lain;

b. Dengan adanya kemampuan
perusahaan untuk bersaing dengan

Ibid, hlm 6-7.
p-ISSN 2354-5976, e-ISSN 2580-7382

https://journal.uniku.ac.id/index.php/unifikasi

sendirinya kemajuan perusahaan akan dicapai, sehingga membawa dampak positif kepada pengusaha dan kesejahteraan para pekerja/buruh; ${ }^{26}$

4. Forum komunikasi untuk mengkoordinasikan lembaga-lembaga ketenagakerjaan yang ada di dalam perusahaan (GKM, TQM, P2K3, KP, ISO,SP) agar dapat terjalin hubungan antara lembaga yang satu dengan yang lainnya secara terkoordinatif, terstruktur, efektif, efisien dan berkesinambungan.

Berdasarkan paparan di atas, maka LKS Bipartit dapat melaksanakan fungsi koordinatif terhadap semua lembaga ketenagakerjaan yang ada di perusahaan, seperti: Panitia Pembina Keselamatan dan Kesehatan Kerja (P2K3), Koperasi Pekerja/Buruh (KP), Gugus Kendali Mutu (GKM), Total Quality Mutu (TQM), International Organization For Standarzation (ISO), dengan cara meningkatkan kerjasama antar lembagaIembaga ketenagakerjaan tersebut, atau Lembaga Kerjasama Bipartit berfungsi sebagai forum komunikasi untuk mengkoordinasikan lembaga-lembaga ketenagakerjaan yang ada di dalam perusahaan agar dapat terjalin hubungan antara lembaga yang satu dengan yang lainnya ${ }^{27}$ secara terkoordinatif, terstruktur, efektif, efisien dan berkesinambungan.

Lembaga Kerja Sama Bipartit sangat memegang peranan yang sangat menentukan sebagai forum untuk meningkatkan kerjasama dalam segala urusan ketenagakerjaan yang dilakukan oleh lembaga-lembaga ketenagakerjaan di dalam

\footnotetext{
26 Ibid, hlm 7.

27 Ibid, , hlm 7.
} 
UNIFIKASI : Jurnal IImu Hukum, Volume 05 Nomor 01, Januari 2018

perusahaan (P2K3, P2K3, GKM,TQM, KP dan lain-lain), melalui forum Lembaga Kerja Sama Bipartit, lembaga-lembaga ketenagakerjaan di dalam perusahaan tersebut berhak untuk mengeluarkan pendapatnya, berhak menyatakan keinginannya, cita-citanya yang berkaitan dengan visi, misi, tujuan lembagalembaga ketenagakerjaan ketenagakerjaan tersebut yang selaras dengan tujuan akhir sistem hukum hubungan industrial, yaitu "keuntungan perusahaan yang berkorelasi dengan kesejahteraan pekerja/buruh dan keluarganya", tegasnya keinginan, cita-cita, visi, misi, tujuan lembaga-lembaga ketenagakerjaan tersebut dapat disalurkan melalui forum kumunikasi Lembaga Kerja Sama Bipartit. Adanya permasalah yang timbul di masyarakat merupakan agenda tetap bagi pemerintah untuk mencari solusi yang terbaik dalam pemecahannya berupa kebijakan. ${ }^{2}$ Henny mengatakan bahwa then one as the deciding factor in holding power is the norm or law. ${ }^{3}$

Lembaga Kerja Sama Bipartit, mengangut prinsip demokratis dengan tujuan untuk menegakan hukum ketenagakerjaan, yaitu sebagai forum komunikasi yang menjamin kebebasan lembaga-lembaga ketenagakerjaan yang ada dalam perusahaan dalam mencapai keinginan, cita-cita, visi, misi

2 Suwari Akhmaddhian, Pengaruh Kebijakan Pemerintah Daerah Dalam Konservasi Sumber Daya Air terhadap Kesadaran Lingkungan Masyarakat Kabupaten Kuningan, Jurnal Unifikasi, ISSN 2354-5976 Vol. 04 Nomor 01 Januari $2017 \mathrm{hlm} .4$.

3 Henny Nuraeny \& Tanti Kirana Utami, The Victim Handling Model of Human Trafficking through Economic Independence, Vol. 16 No. 2 Mei 2016, FH-UNSOED, HIm. 121. DOI. 10.20884/1.jdh.2016.16.2.507.
p-ISSN 2354-5976, e-ISSN 2580-7382

https://journal.uniku.ac.id/index.php/unifikasi

dan tujuannya, dalam pengertian bahwa kebebasan disini adalah kebebasan dalam batas-batas peraturan perundang-undangan, sedangkan peraturan perundang-undang disini peraturan perundang-undangan ketenagakerjaan, baik berupa Norma Kerja (labour Legislation) yang bersifat Makro Minimal maupun berupa Syarat Kerja (Term of Employment) yang bersifat Mikro Kondisional yang dibuat secara partisipatif, muatannya aspiratif dan rinciannya limitatif sehingga tercipta suatu kepastian hukum untuk menjamin terlaksananya hak dan kewajiban semua pihak yang terlibat) dalam suatu hubungan industrial (perusahaan, pekerja/buruh, pemerintaha), demi tercapai hubungan industrial yang harmonis (Industrial Peace). Hal ini selaras dengan pengertian bahwa one of the main factors and actors who play a role in realization of clean government and good governance is bureaucracy. ${ }^{4}$

\section{SIMPULAN}

Hasil penelitian dan penjambaran di atas, peneliti memiliki kesimpulan sebagai berikut

1. korelasi antara negara kesejahteraan dengan HAM dalam perlindungan tenaga kerja adalah Hak setiap warga negara Indonesia untuk menyampaikan pikiran dengan lisan. tulisan. dan sebagainya secara bebas dan bertanggung jawab sesuai dengan ketentuan peraturan perundang-undangan yang berlaku dalam suatu forum komunikasi Lembaga Kerja Sama Bipartit. Tujuan Lembaga Kerja Sama Bipartit, adalah menciptakan hubungan industrial yang harmonis,

\footnotetext{
${ }^{4}$ Tanti Kirana Utami, The Position of Filling Pratama High Leadership in Cianjur Regency Under Good Governance Consept. Jurnal Dinamika Hukum, volume 17 No. 02 Mei 2017, FH-UNSOED, 2017, hlm 141.
} 
dinamis, dan berkeadilan untuk kelangsungan hidup, pertumbuhan, dan perkembangan perusahaan, termasuk kesejahteraan pekerja/buruh. Nilai-nilai Pancasila dan Undang-Undang Dasar 1945 merupakan kerangka utama dari suatu sistem hukum hubungan industrial dan menentukan arah bagi para pelaku dalam proses produksi barang dan jasa untuk mencapai kesejahteraan bagi semua pihak. Karena Pancasila dan UndangUndang Dasar 1945 merupakan kerangka utama dari suatu sistem hukum hubungan industrial, maka berdasarkan isi kaidahnya hukum hubungan industrial masuk golongan Kaidah Hukum Publik (Vide Pasal 102 s/d 135 Undang-Undang Nomor 13 Tahun 2003 tentang Ketenagakerjaan).

2. peran Lembaga Kerjasama Bipartit dalam memberikan perlindungan terhadap hak perkerja/buruh adalah melakukan pertemuan secara periodik dan/atau sewaktu-waktu apabila diperlukan, mengkomunikasikan kebijakan pengusaha dan aspirasi pekerja/buruh dalam rangka mencegah terjadinya permasalahan hubungan industrial di perusahaan, menyampaikan saran pertimbangan dan pendapat kepada pengusaha, pekerja/buruh, serikat pekerja/serikat buruh dalam rangka penetetapan dan kebijakan perusahaan baik penetetapan dan kebijakan perusahaan yang berkaitan dengan pembentukan, pelaksanaan, pengembangan lembaga-lembaga ketenagakerjanaan (GKM, TQM, ISO, P2K3, Koperasi Karyawan dan lain-lain), maupun jenisjenis kebijakan perusahaan lainnya.

\section{SARAN}

Berdasarkan hal - hal yang telah diuraikan diatas maka penulis dapat memberikan saran-saran yaitu Sebaiknya dalam penyelesaian perselisihan hubungan industrial dilakukan dengan cara musyawarah menuju ke arah persatuan dengan mengutamakan ikut sertanya semua pihak yang terlibat dalam hubungan industrial serta berpangkal tolak pada sikap harga menghargai setiap pendirian, keinginan semua pihak yang terlibat dalam hubungan industrial.

\section{DAFTAR PUSTAKA}

Adhyaksa, Gios. Penerapan Asas Perlindungan Yang Seimbang Menurut KUHPerdata Dalam Pelaksanaan Perjanjian Kerja Untuk Waktu Tertentu Dihubungkan Dengan UndangUndang Nomor 13 Tahun 2003 Tentang Ketenagakerjaan, Jurnal Unifikasi, ISSN 2354-5976 Vol. 3 No. 2 Juli 2016, FH-UNIKU.

Akhmaddhian, Suwari. Pengaruh Kebijakan Pemerintah Daerah Dalam Konservasi Sumber Daya Air terhadap Kesadaran Lingkungan Masyarakat Kabupaten Kuningan, Jurnal Unifikasi, ISSN 2354-5976 Vol. 04 Nomor 01 Januari 2017.

Aminanto, KIF. 2017, Politik Hukum Pidana, Disparitas Putusan Hakim dalam Tindak Pidana Korupsi, Cetakan ke I, Jember : Katamedia.

Azhary, 1995, Negara Hukum Indonesia, Analisis Yuridis Normatif Tentang Unsur-Unsurnya. Jakarta : UI Press.

Busroh, Abu Daud. 1990, Ilmu Negara, Jakarta : Bumi Aksara. 
UNIFIKASI : Jurnal IImu Hukum,

Volume 05 Nomor 01, Januari 2018

Kansil, C.S.T. dan Christine S.T. Kansil, 2007

Hukum Tata Negara di Indonesia,

Jakarta : Sinar Grafika.

Kementerian Tenaga Kerja dan Transmigrasi

Republik Indonesia. 2013. Sekretariat

Jendral Pusat Pendidikan dan Pelatihan

Pegawai, Modul Lembaga Bipartit,

Jakarta.

Mahfud MD, Moh. 2009, Politik Hukum di Indonesia, Cetakan I, II dan III, Jakarta: PT Raja Grafindo Persada.

Nuraeny, Henny \& Tanti Kirana Utami, The Victim Handling Model of Human Trafficking through Economic Independence, Vol. 16 No. 2 Mei 2016, FH-UNSOED, DOI. 10.20884/1.jdh.2016.16.2.507.

Padmo Wahjono, Padmo. 1983, Indonesia Berdasarkan Atas Hukum, Jakarta : Ghalia Indonesia.

Suwarto. 2003. Hubungan Industrial Dalam Praktek, Jakarta : Asosiasi Hubungan Industrial Indonesia.

Tanti Kirana Utami, Tanti. The Position of Filling Pratama High Leadership in Cianjur Regency Under Good Governance Consept. Jurnal Dinamika Hukum, volume 17 No. 02 Mei 2017, FH-UNSOED, 2017.

Tim Pengajar PIH Fakultas Hukum Unpar, 1995, Pengantar PIH, Universitas Katolik Parahyangan Fakultas Hukum, Bandung.

Undang Undang Dasar Negera Republik Indonesia Tahun 1945.

Undang-Undang Nomor 13 Tahun 2003 tentang Ketenagakerjaan.
p-ISSN 2354-5976, e-ISSN 2580-7382

https://journal.uniku.ac.id/index.php/unifikasi 